\title{
Pengaruh Metode Pembelajaran E-Learning dan Snowball Throwing Terhadap Prestasi Belajar Mahasiswa di Kelas Kalkulus Institut Teknologi dan Bisnis Stikom Bali
}

\author{
Gusti Ayu Made Arna Putri \\ Institut Teknologi dan Bisnis Stikom Bali \\ gustiayu.arna@gmail.com
}

\begin{abstract}
ABSTRAK
Model pembelajaran dengan metode E-learning dan Snowball Throwing mengacu pada dua metode pembelajaran yang berbeda yaitu model pembelajaran modern dan konvensional. Metode $E$ learning atau electronic learning melatih mahasiswa untuk belajar secara mandiri di mana pun dan kapanpun. Metode Snowball Throwing adalah kegiatan pembelajaran yang disertai dengan permainan pelemparan kertas berisi pertanyaan yang dibentuk menyerupai bola salju, sehingga kegiatan belajar mengajar menjadi jauh lebih menyenangkan. Subjek yang diteliti dalam penelitian ini adalah mahasiswa mata kuliah Kalkulus semester genap di Institut Teknologi dan Bisnis STIKOM Bali. Penelitian melibatkan dua kelas Kalkulus, kelas yang pertama diberi perlakuan kedua metode dan kelas yang kedua hanya diberi metode konvensional. Tujuan dari penelitian ini adalah untuk melihat pengaruh penerapan metode E-Learning dan Snowball Throwing pada kelas Kalkulus tersebut. Pengujian dilakukan dengan independent $T$ test atau uji T. Hasil dalam penelitian ini adalah perbandingan hasil belajar pada masing-masing kelas Kalkulus.
\end{abstract}

Kata kunci: kalkulus, metode e-learning, metode snowball throwing.

\section{ABSTRACT}

Learning method with E-Learning and Snowball Throwing methods referring to two defferent learning method is modern elearning and convensional model. E-Learning method or electronic learning train students to study independently anywhere and anytime. Snowball Throwing method is a learning activity that accompanied by paper throwing games with a snowball shape so the teaching and learning activity become more fun. The examined subjects in this study is college students that take Calculus class in even semester at the Institute of Technology and Business STIKOM Bali. The study involve two Calculus classes, the first class was given both methods and the second class was given the conventional methodonly. The purpose of this study is to see impact of application of E-Learning and Snowball Throwing method on the Calculus classes. The test is done by independent t test. The results of this study is comparison of learning outcomes in each Calculus classes.

Keywords: calculus, e-learning method, snowball throwing method. 


\section{PENDAHULUAN}

Di era globalisasi seperti sekarang ini dunia sangat bergantung terhadap kemajuan teknologi, tidak terkecuali masyarakat di Indonesia. Teknologi mempunyai pengaruh yang sangat besar di berbagai bidang. Salah satunya teknologi sangat berpengaruh dalam bidang pendidikan. Pendidikan memiliki tujuan membentuk watak dan mencerdaskan kehidupan bangsa sehingga membentuk peradaban yang lebih baik di masa mendatang. Pengembangan potensi peserta didik tersebut tidak luput dari dua kegiatan penting dalam dunia pendidikan yaitu proses belajar dan pembelajaran.

Menurut Oemar Hamalik (2006) ada beberapa unsur yang mempengaruhi sistem pembelajaran yaitu unsur manusiawi, fasilitas yang tersedia, serta aturan yang saling behubungan dan mempengaruhi tercapainya tujuan pembelajaran. Banyak cara yang digunakan demi menjadikan proses belajar mengajar menjadi lebih mudah bagi para peserta didik. Metode yang menjadi tren saat ini adalah metode pembelajaran berbasil internet E-learning dan metode konvensional Snowball Throwing. Menurut Hanum (2013) metode E-learning atau elektronic learning adalah metode yang dianggap mampu mengatasi masalah pendidikan baik di negara maju maupun negara berkembang karena metode E-learning dirasa mampu mengatasi masalah keterbatasan jarak dan waktu. Sedangkan metode Snowball Throwing menurut Rahman (2015) merupakan salah satu metode pembelajaran, di mana mahasiswa diberikan kesempatan dan kebebasan untuk membangun maupun menciptakan suatu pengetahuan.

Beberapa metode pembelajaran terkadang tidak cocok diterapkan dalam semua bidang ilmu contohnya metode Snowball Throwing. Metode Snowball Throwing kurang tepat digunakan untuk mata pelajaran atau bidang studi ilmu pengetahuan sosial, karena ilmu pengetahuan sosial memiliki cakupan ilmu yang sangat luas dan membutuhkan pembaharuan yang terus menerus karena ilmunya yang selalu berkembang (Akhiriyah, 2011). Sehingga untuk metode Snowball Throwing bidang ilmu yang lebih cocok digunakan adalah jenis-jenis bidang ilmu pengetahuan alam atau ilmu eksak yang cenderung menggunakan penyelesaian dengan rumus yang relatif tetap. Seperti penelitian Aminoto yang membahas tentang penerapan metode E-learning berbasis Schoology untuk meningkatkan aktivitas dan hasil belajar dalam materi usaha dan energi di Kelas XI SMA N 10 Kota Jambi (Aminoto, 2014) dan penelitian Pravitasari tentang penerapan metode Snowball Throwing untuk melihat peningkatkan hasil belajar pada mata pelajaran matematika siswa kelas IV SDN Tanjungrejo 1 Malang (Pravitasari, 2011).

Berdasarkan latar belakang masalah yang telah diuraikan maka peneliti tertarik untuk mengadakan penelitian tentang eksperimen pembelajaran dengan mengkombinasikan metode E-learning dan metode Snowball Throwing di kelas Kalkulus. Hasil yang ingin dicapai dalam penelitian ini adalah melihat ada tidaknya perbedaan nilai Kalkulus dari kelas yang diberi metode E-learning dan Snowball Throwing dibandingkan dengan kelas yang hanya diberi metode konvesional.

\section{METODE}

\subsection{Prosedur Penelitian}

Penelitian ini dilakukan di Institut Teknologi dan Bisnis STIKOM Bali dengan waktu penelitian sembilan bulan. Subjek dalam penelitian ini adalah seluruh mahasiswa kelas kalkulus 
CA181 dan kelas kalkulus VA181. Teknik pengumpulan data yang digunakan yaitu teknik observasi langsung di kelas. Data diperoleh dengan mengumpulkan nilai akhir mahasiswa kelas kalkulus CA181 dan VA181.

\section{Langkah-Langkah Penelitian}

Tahan awal dalam penelitian ini yaitu dengan melakukan uji pretest pada kelas kalkulus. Terdapat dua kelas yang menjadi subjek penelitian yaitu kelas kalkulus CA181 dan VA181. Kelas CA181 diberi perlakuan dengan metode E-learning dan Snowball Throwing sedangkan kelas VA181 hanya diberi metode konvensional. Kemudian diperoleh nilai akhir mahasiswa masing-masing kelas tersebut. Lakukan uji T untuk melihat pengaruh metode E-Learning dan Snowball Throwing. Selanjutnya bandingkan hasil pengujian di kelas CA181 dan kelas VA181.

\subsection{Desain Penelitian}

Peneliti menggunakan data kuantitatif yaitu data yang berwujud angka atau bilangan yang diperoleh dari hasil nilai akhir mahasiswa kelas Kalkulus di Institut Teknologi Dan Bisnis Stikom Bali. Penelitian ini merupakan penelitian eksperimental dengan teknik observasi, dimana peneliti mengumpulkan data dengan pengamatan secara langsung di kelas. Teknik analisis yang digunakan dalam penelitian ini yaitu teknik analisis data statistik. Teknik analisis data stattistik merupakan suatu teknik bagaimana cara-cara mengumpulkan data atau fakta, mengolah, menyajikan, dan menganalisa, sehingga nantinya dapat ditarik kesimpulan serta pembuatan keputusan yang cukup beralasan berdasarkan fakta dan analisa di kelas.

\section{HASIL DAN PEMBAHASAN}

\subsection{Statistika Deksriptif Uji Pretest}

Pada uji statistik deskriptif diperoleh hasil nilai mata kuliah Diskrit untuk Uji Pretest tertuang pada Tabel 1. Dalam uji pretest, jumlah mahasiswa yang mengikuti ujian Diskrit di kelas CA181 adalah 24 orang dengan nilai rerata sebesar 82,08. Jumlah mahasiswa yang mengikuti ujian Diskrit di kelas VA181 adalah 23 orang dengan rerata sebesar 80,87. Gambaran Visualisasi nilai rerata mata kuliah Diskrit untuk kedua kelas dapat dilihat pada Gambar 1.

Tabel 1. Nilai Mata Kuliah Diskrit untuk Uji Pretest

\begin{tabular}{cccc}
\hline Kelas & $\mathrm{N}$ & Mean & Std. Deviation \\
\hline CA181 & 24 & 82.0833 & 8.83627 \\
VA181 & 23 & 80.8696 & 6.68312 \\
\hline
\end{tabular}




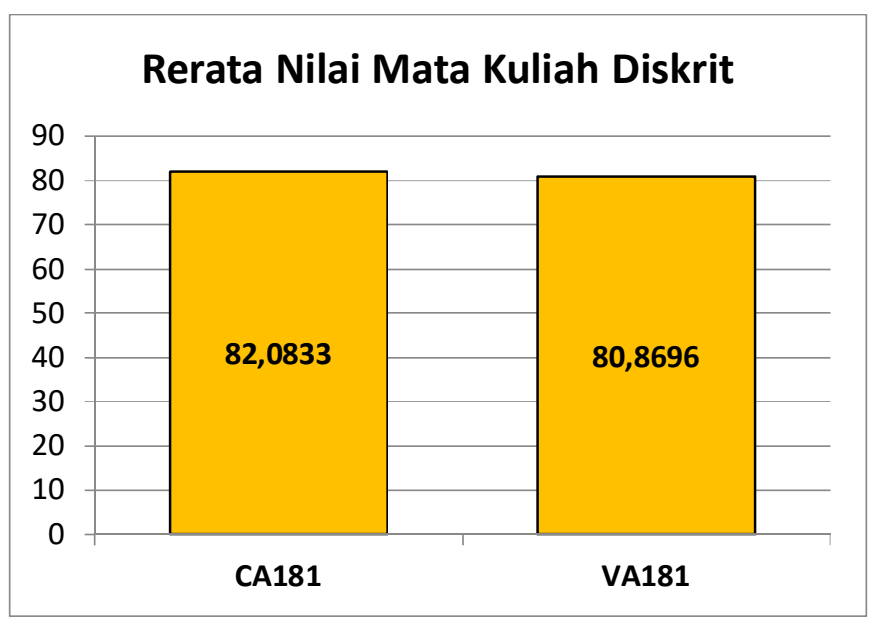

Gambar 1. Nilai Rerata Mata Kuliah Diskrit di kelas CA181 dan VA181

\subsection{Uji Pretest}

Tabel 2 menjelaskan hasil nilai t-hitung di kelas CA181 dan VA181 pada uji pretest. Berdasarkan hasil analisis diperoleh nilai t-hitung sebesar 0,529 dengan nilai signifikansi sebesar 0,599. Nilai signifikansi yang lebih besar dari 0,05 menunjukkan bahwa tidak terdapat perbedaan yang signifikan pada kelas CA181 dan VA181. Kesimpulan yang diperoleh bahwa hipotesis null $\left(\mathrm{H}_{0}\right)$ yang menyatakan bahwa tidak terdapat perbedaan yang signifikan antara kelas CA181 dan VA181 diterima.

Tabel 2. Uji Pretest untuk Kelas CA181 dan VA181

\begin{tabular}{cc}
\hline t-hitung & Signifikansi \\
\hline 0,529 & 0,599 \\
\hline
\end{tabular}

\subsection{Statistika Deksriptif Uji Hipotesis}

Pada uji statistik deskriptif diperoleh hasil nilai mata kuliah Kalkulus untuk Uji Hipotesis terangkum pada Tabel 3. Dalam uji beda pada dua kelompok perlakuan dimana kelas CA181 diberi metode pembelajaran E-Learning dan Snowball Throwing dan kelas VA181 hanya diberi metode konvensional. Berdasarkan hasil analisis diperoleh nilai rerata untuk kelas CA181 sebesar 76,44 dan kelas VA181 sebesar 71,33. Gambaran Visualisasi nilai rerata mata kuliah Kalkulus untuk kedua kelas dapat dilihat pada Gambar 2.

Tabel 3. Nilai Mata Kuliah Kalkulus untuk Uji Hipotesis

\begin{tabular}{cccc}
\hline Kelas & $\mathrm{N}$ & Mean & Std. Deviation \\
\hline CA181 & 26 & 76.4396 & 10.80530 \\
VA181 & 30 & 71.3333 & 7.03953 \\
\hline
\end{tabular}




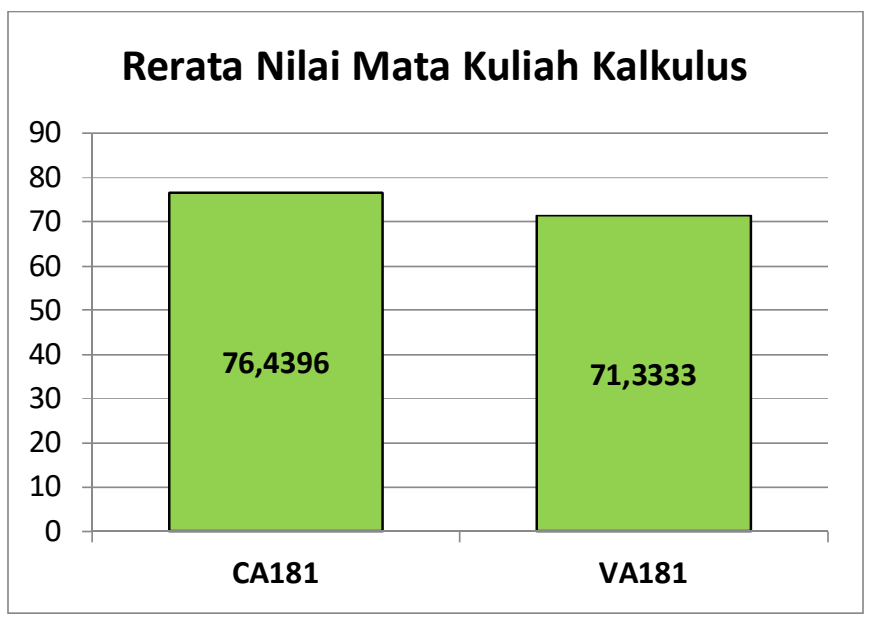

Gambar 2. Nilai Rerata Mata Kuliah Kakulus di kelas CA181 dan VA181

\subsection{Uji Hipotesis}

Pada uji hipotesis diperoleh hasil analisis nilai t-hitung di kelas CA181 dan VA181 terangkum pada Tabel 4. Berdasarkan hasil analisis diperoleh nilai t-hitung sebesar 2,122 dengan nilai signifikansi sebesar 0,038. Nilai signifikansi yang lebih kecil dari 0,05 menunjukkan bahwa terdapat perbedaan yang signifikan pada kelas CA181 dan VA181. Kesimpulan yang diperoleh bahwa hipotesis null $\left(\mathrm{H}_{0}\right)$ yang menyatakan bahwa tidak terdapat perbedaan yang signifikan antara kelas CA181 dan VA181 ditolak.

Tabel 4. Uji Beda untuk Kelas CA181 dan VA181

\begin{tabular}{cc}
\hline $\mathrm{t}$ hitung & Signifikansi \\
\hline 2,122 & 0,038 \\
\hline
\end{tabular}

\section{SIMPULAN}

Berdasarkan hasil analisis pretest dengan mata Diskrit dapat disimpulkan bahwa tidak terdapat perbedaan antara kelas CA181 dan VA181. Bahwa kemampuan mahasiswa di kedua kelas tersebut homogen. Berdasarkan hasil analisis nilai Kalkulus dari kelas yang diberi metode E-learning dan Snowball Throwing dibandingkan dengan kelas yang hanya diberi metode konvesional dapat disimpulkan bahwa terdapat perbedaan antara kelas CA181 dan VA181.

\section{DAFTAR PUSTAKA}

Akhiriyah, D.Y. (2011). Penerapan Model Pembelajaran Snowball Throwing untuk Meningkatkan Kualitas Pembelajaran IPS pada Siswa Kelas V SDN Kalibanteng Kidul 01 Kota Semarang. Jurnal Kreatif: Jurnal Pendidikan dasar, Vol 1, No 2.

Aminoto (2014). Penerapkan Metode E-learning Berbasis Schoology untuk Meningkatkan Aktivitas dan Hasil Belajar dalam Materi Usaha dan Energi di Kelas XI SMA N 10 Kota Jambi. Jurnal Sainmatika: Jurnal Sains dan Matematika Universitas Jambi, Vol 8, No 1.

Hamalik, O. (2006). Proses Belajar Mengajar, Jakarta: PT. Bumi Aksara. 
108 | Gusti Ayu Made Arna Putri - Pengaruh Metode Pembelajaran E-Learning dan Snowball Throwing Terhadap Prestasi Belajar ....

Hanum, N.S. (2013). Keefektifan E-learning Sebagai Media Pembelajaran. Jurnal Pendidikan Vokasi, Vol 3, No 1.

Pravitasari, A. (2011). Penerapan Pembelajaran Kooperatif Snowball Throwing untuk Meningkatkan Hasil Belajar pada Mata Pelajaran Matematika Siswa Kelas IV SDN Tanjungrejo 1 Malang. Skripsi. Universitas Negeri Malang: Ilmu Pendidikan.

Rahman, A. (2015). Penerapan Metode Snowball Throwing untuk Meningkatkan Hasil Belajar IPS Siswa Kelas V pada SDN No.1 Pantolobete. Jurnal Kreatif Tadulako Online, Vol 5, No 4: 154 - 167. 